\title{
The Public Library Serves The University Student
}

BY HAROLD L. HAMIILL

$\mathrm{T}_{\mathrm{s}}$ HE MOST SERIOUS service problem faced by many public libraries today is that of meeting the needs of the student in the college or university located in a large city or metropolitan area. This paper excludes from our consideration the situation such as that at Princeton or at Stanford, where the great majority of students live on or near the campus, and thus have access to the university library whenever it is open.

Los Angeles is the seat of two large urban universities - the University of Southern California, with an enrollment of nearly seventeen thousand students, and the University of California at Los Angeles, with about the same number. The Los Angeles State College has an enrollment of over 14,000, and the newer San Fernando Valley State College will soon approach, or even exceed, this size. Numerous other smaller colleges and specialized schools are scattered throughout Los Angeles and the metropolitan area. Relatively few of the students enrolled at the universities and the state colleges live on campus or even near it. The city of Los Angeles alone spreads over almost 460 square miles, and the county covers ten times that area. Public transportation is generally poor, and in some parts of the area completely nonexistent, with the result that our people are highly dependent on automobile transportation.

Students spend only a part of their day on campus. After they have attended their classes, they transport themselves by automobile, often in car pools, back to homes located in parts of the metro-
Mr. Hamill is Librarian, Los Angeles Pub. lic Library. This paper was given at the ALA Conference, Cleveland, July 1961.

politan area far removed from the university or college library. Under these circumstances, it is not surprising that for reference and reading needs connected with his courses the student turns to the nearest public library which has suitable materials. In Los Angeles the student finds that most of his needs can be met in the collections of the Los Angeles Public Library, which, although they are certainly not unlimited, do include over 2,700,000 volumes and twentyfive thousand serial titles. Student use of the central library is, of course, particularly heavy, but our larger regional branches with collections numbering up to seventy-five thousand volumes are also drawn upon to supply a great many student needs. I am not trying to say that we have by any means all the services and all the copies needed, but, generally speaking, students have discovered that they have a fairly good chance of finding what they want at the public library.

This situation, I am sure, from what I have been told and from what I have seen in our professional literature, is one which holds true in other large urban centers. The many difficulties encountered by the public library in meeting this onrush of university and college students are augmented by armies of other students of all ages from elementary grades through high school. Although students have always been an important section 
of the public library's clientele, since the end of the war, and particularly during the past three or four years, public libraries have actually been overwhelmed at many times by the student horde. In fact, many members of our library staff are considerably concerned that the nonstudent adult feels unwelcome in the confusion and hubbub created by student use. In many libraries, students have become the tail that wags the dog, and other would-be users of the library are simply not able to get access to the materials they need or to receive the professional services they have every right to expect.

Transportation problems loom large in Los Angeles, but putting them aside for a moment, I think we should ask at this point whether university and college libraries are adequate for present-day student needs. In 1959 the Council of the American Library Association adopted an official statement of Goals for Action. The first item on the list was this: "Library collections and services for every school, college, and university that will support the instructional program and stimulate student interest in reading and in continued self-education." Let me stress that this is still a goal, and is far from actuality. The universities of Los Angeles which I mentioned earlier both have excellent libraries managed by intelligent and progressive librarians. But here, as elsewhere in California and throughout the nation, several factors have operated to keep library facilities in universities and colleges well below a level of complete adequacy to meet student needs. First of all, in recent years the university and college populations have expanded enormously. The sheer bulk of students has produced a demand for duplication of copies far beyond the ability of most university and college libraries to supply. Meanwhile, changed patterns of education at all levels of schooling are placing heavier reliance on the use of source materials and serial publications, less on single textbook and classroom lecture methods. Small wonder then that students hunt diligently throughout the metropolitan area for the books or serial files needed for their reading assignments or papers. In the social sciences department of our central library within the past year or two we have had to put on special reference loan for control purposes approximately fourteen hundred titles which our experienced staff knows will be called upon heavily by students. In Los Angeles, and I am sure elsewhere, the need for such drastic measures has been compounded by the fact that many new colleges and junior colleges have been established and their libraries have not yet had an opportunity to achieve anything like the necessary depth of collections or adequate duplication of copies. Under these circumstances, is it any wonder that students follow every possible and practical avenue to meet their full library needs?

\section{Public Library's Responsibility}

I have described some of the difficulties under which the public library labors in this situation. It is true that students have overrun its facilities, that they have in some cases driven out adult nonstudent users. Perhaps we should ask at this point whether the public library can and should continue to serve the university and college student. It is my continued and firm belief that it must accept the responsibility to serve students to the best of its ability. Not only would the public library be socially unjustified in erecting barriers against students, but it should actually welcome the opportunity to encourage students to become life-long consumers of its wares.

Moreover, I believe that our larger public libraries are in a unique position to supplement the university and college libraries in meeting the needs of students. The average large public library has long files of periodicals, serials, 
and government documents, important collections of specialized pamphlets and materials in microform. Unless the student is enrolled in a university with a very large collection of materials, he may not be able to find some of these things in his own educational institution and must perforce use the public library.

One automatic check on student use of public libraries lies in the fact that few public libraries buy textbooks as such. In the Los Angeles Public Library's policy statement on library service to students, our position on textbooks is stated thus:

It is the responsibility of the Los Angeles Public Library to provide circulating materials and reference service to meet or supplement the needs of students. Local educational institutions are expected to supply textbooks and related materials for student use. Textbooks purchased by the library are acquired primarily for subject content and value to the general reader and are duplicated only in sufficient quantity to meet normal community demands. The use of rare, irreplaceable materials is restricted to research purposes.

It is true that the university collections and public library collections taken together cannot completely supply the need for duplicate copies. It is my hope that the increasing publication of classics and specialized titles in paperback form will be a substantial contribution to the need for heavy duplication. Paperbacks are generally helpful, however, only in the field of monographs. For periodicals and serials with backfiles running from twenty to fifty years or more, the student will continue to be completely dependent upon the larger and longer-established libraries, whether university or public. The newer educational methods mentioned earlier lean heavily on assignments involving serial titles. Visitors to our central library from other cities and other countries, both librarians and laymen, never fail to be impressed by the great number of students using our bound periodicals and other serials. Many of these, of course, are high school students. In former days a student taking a course in history, art, philosophy, or one of the social sciences might have need to consult this kind of material once or twice a year for a term paper. But under the present methods some of our students, particularly the superior ones, are involved in assignments which bring them to the library to consult serial files two or three times a month or oftener. Therefore, where we used to have scores of requests of this kind in a week we now have hundreds or even thousands.

It seems to me, then, that the public library has a golden opportunity to introduce the student at an impressionable age to an institution which, as an educated person, he should use freely all of his life. Students of all ages and of all categories, if they are willing to settle down and behave themselves, should be made welcome in their public library. In many cases the student's way of life and his transportation habits actually make his use of the public library mandatory. This is not to say that the public library should unduly solicit the patronage of this important group of users or that it should attempt to serve them to the extent of penalizing the general body of adult users. But certainly, as young citizens, students have a right to use their public library as fully as their needs require and circumstances permit. Keeping a perfect balance between the needs of students and those of the other adult readers is, I realize, perhaps more easily said than done.

In practically every one of our major cities someone, usually the executive of the largest public library in the area, has made an attempt to bring together school authorities, other librarians, curriculum planners, college and university authorities from various levels and in various groupings to see whether a more intelligent and cooperative job of library serv- 
ice to students can be achieved. To date, these attempts have produced some accomplishments, but I am afraid that in most cases not enough headway has been made. At two gatherings of this kind in Los Angeles, I have received the impression that many of the college and university librarians in the area feel that the problem would be solved if the public library would only set up residence requirements for the use of its materials by students, and thereby turn back to their college or university at least some of the army of students. I cannot believe that this is a valid solution to what $I$ agree is a difficult problem. To library users patterns of accessibility are more important than legal boundaries. In meetings of college and university librarians with public librarians, attention is also often given to cooperative agreements for acquisition of materials. Although such agreements are healthy, particularly in the area of more highly specialized research materials, we must remember that demand for use is likely to override strictly logical divisions of material. In parceling out fields of specialization, therefore, we must remember to be realistic, and must be generous in planning for considerable duplication in the vast areas of materials used by undergraduates in colleges or universities.

Bringing public librarians and university librarians together only to commiserate or to plan ways to "share the poverty" does not attack the real problem. How then can they cooperate to real purpose?

\section{Lack of Basic Planning}

First, let me say that I wish I could report that all of this greatly increased use by students of libraries has come about in an orderly and intelligent way. I wish I could think that it is the product of years of informed planning and detailed knowledge on the part of educators of all levels-administrators, cur- riculum planners, teachers, and librarians. But such is certainly not the case. Curriculum planners make no attempt to find out whether the libraries in their institutions can meet the needs of the curriculum. Teachers directly responsible for assignments are often uninformed and oblivious to what those assignments require in the way of library materials. Certainly administrators and appropriating bodies seem unaware of the fact that the changed curriculum has placed vast new demands upon libraries and even more unaware that their libraries are ill-equipped to meet these demands. I am repeating only what has been said a hundred times before when I say that public librarians and university librarians need to work together through our professional associations and at the local level on the serious problem of educating teachers in the student use of libraries. At the local level we need also to know more about each other's resources in order to do an intelligent job of using what we have to the best advantage.

Even more importantly, the public librarian and university and college librarian should aid each other in the presentation of their financial needs to administrators and appropriating bodies. We need to understand each other's situation and to help each other develop strategy. As an example of what I mean by strategy, let me cite a comment made at a Los Angeles meeting called to discuss the student problem. It was suggested that perhaps the Los Angeles Public Library should refuse all interlibrary loans to universities and colleges in the area, thus strengthening the budget request made by the college and university libraries for book money to purchase the materials they lack. Parenthetically, I might point out that some of the public libraries in the Los Angeles metropolitan area are taking what might seem on the surface to be a step backward by canceling their reciprocal agreements with neighboring cities and raising their non- 
resident fees. While this certainly seems to go against the pattern of cooperation toward which libraries have been moving, it may actually be a painful but necessary step to convince appropriating bodies and the general public that the word "free" in "free public library" is not to be taken too literally.

Not only do we need greater understanding and closer cooperation between the libraries of educational institutions on the one hand and public libraries on the other, but we certainly need a vast increase in the resources of both. While there is a faint chance that American education may not continue to go in the direction of the pursuit of excellence, of toughened-up courses, and of greatly expanded educational institutions, it seems likely that these trends will continue and even be strengthened. Educational costs will continue to rise and the administrative librarian must be ready to fight for a great increase in library budgets.

In the Library Quarterly January 1960 , Sara Fenwick described the situation created by students of high school age in a suburban part of Chicago. From the facts she set forth, the conclusion was clear that the resources of all the libraries available, both school and public, were inadequate to meet student needs. It was obvious that the problem could not be solved simply by working out understandings or cooperative measures between the two kinds of institutions. This is the same kind of problem that exists in university libraries and public libraries, namely, that there are simply not enough books, librarians, or physical facilities to meet the needs of modern education. In the long run, the only real solution lies in the upgrading of libraries of all kinds. Such upgrading will require the establishment and general acceptance of high standards and the achievement of those standards through adequate financing of library service.

At a recent meeting of public librarians with college, university, and school librarians, Everrett Moore, assistant librarian at UCLA, made what I regarded as the most telling comment of the afternoon. He said that the total library resources of the metropolitan area should be regarded as a vast pool, to be drawn upon by users of all kinds. I fully agree with him. I would only add that if it is to serve the purposes of modern society to the full, this vast pool must be greatly deepened and broadened through the heroic efforts of all of us.

\section{Funds for Archivists, Librarians, Researchers}

The Harvard Graduate School of Business Administration announces the availability of funds to aid archivists, librarians, and researchers interested in investigating topics in economic and business history or in studying the acquisition and handling of archival material, manuscripts, and books in this field. The school's unique resources in these areas will be available to such persons during the summer of 1962. Members of the Business History Group and the staff of Baker Library will be available for consultation and guidance, but applicants who receive assistance will be free to pursue their projects as they think best. The criterion for awarding financial aid will be primarily the extent to which the use of the school's resources can be expected to advance proposed projects. This decision will be made by a committee of faculty members at the Harvard Business School. The amount of aid will be adjusted to the requirements of the individuals who are selected. Inquiries may be addressed to Professor Ralph W. Hidy, Morgan 304, Harvard Graduate School of Business Administration, Soldiers Field, Boston 63, Mass. 